\title{
Selection of an Artificial Diet for Laboratory Rearing of Opogona sacchari (Lepidoptera: Tineidae) (Bojer, 1856)
}

\author{
A Coelho Jr ${ }^{1}$, JM Milanez ${ }^{2}, \mathrm{R}$ de Andrade Moral ${ }^{3}$, CGB Demétrio $^{3}$, JRP Parra $^{1}$ \\ 1Dept of Entomology and Acarology, Escola Superior de Agricultura "Luiz de Queiroz" (ESALQ), Piracicaba, SP, Brasil \\ ${ }^{2}$ Itajaí Experimental Station (EEI), Empresa de Pesquisa Agropecuária e Extensão Rural de Santa Catarina (EPAGRI), Itajaí, SC, Brasil \\ ${ }^{3}$ Dept of Math, Chemistry and Statistics, Escola Superior de Agricultura "Luiz de Queiroz" (ESALQ), Piracicaba, SP, Brasil
}

\section{Keywords}

Banana moth, IPM, biotic potential, quarantine pest

\section{Correspondence}

A Coelho, Dept of Entomology and Acarology, Escola Superior de Agricultura "Luiz de Queiroz" (ESALQ), Avenida Pádua Dias, 11, Bairro Agronomia, Piracicaba, CEP: 13418-900, SP, Brasil; aloisiocoelho@usp.br

Edited by André VL Freitas - UNICAMP

Received 25 May 2016 and accepted 21 March 2017

Published online: 17 April 2017

(C) Sociedade Entomológica do Brasil 2017

\begin{abstract}
The banana moth Opogona sacchari (Bojer) (Lepidoptera: Tineidae) is a polyphagous pest that can cause serious damage, in particular to banana crops in southern Brazil. The insect is a quarantine pest in several countries, including Argentina, the main consumer market for bananas from southern Brazil. Little information is available about the biology and ecology of this moth, such as a suitable diet for laboratory rearing. In order to provide support for integrated pest management of the pest, this study furnished data for selecting two diets suitable for continuous laboratory rearing of $O$. sacchari, one based on dried beans, wheat germ, soy bran, brewer's yeast, and casein and another diet with wheat germ and casein as protein sources. With both diets, the viability of the egg-adult period exceeded $68 \%$, with fertility over 338 eggs per female. A corrected biotic potential analysis gave similar values for the two diets.
\end{abstract}

\section{Introduction}

In several countries, the banana moth Opogona sacchari (Bojer, 1856) (Lepidoptera: Tineidae) causes serious damage to agricultural and ornamental crops including banana, sugarcane, gladiolus, dahlias, yam, bamboo, and potato (Cintra 1975, (EPAGRI) Empresa de Pesquisa Agropecuária e Extensão Rural de Santa Catarina 2016, Raga 2005). Most articles dealing with $O$. sacchari have merely reported the first records in different countries and its host plants (Cintra 1975, Heppner et al 1987). Many countries have designated this insect as a quarantine pest (Milanez et al 2011, (EPPO) European and Mediterranean Plant Protection Organization 2015, (USDA) U.S. Department of Agriculture/ APHIS Animal and Plant Health Inspection Service 2016), including Argentina, a major importer of bananas from Brazil ((SENASA) Servicio Nacional de Sanidad y Calidad Agroalimentaria 2016)). In the 1980s, O. sacchari caused economically significant losses in banana plantations in the state of São Paulo; in 2006, producers' shipments to other countries from the state of Santa Catarina were infested by this pest and rejected by agricultural inspectors (Cintra 1975, Milanez et al 2011).

Despite the importance of $O$. sacchari, few studies deal with aspects of its biology and ecology, information that is required for integrated pest management (IPM) programs. Opogona sacchari outbreaks can occur in periods without rain (low relative humidity) during the winter at the southern hemisphere (Gallo et al 2002). Gianotti et al (1977) studied the insect's larval period on an artificial diet based on bananas, and Bergmann et al (1995) described the larval and pupal periods of $O$. sacchari reared on an artificial diet based on beans, under controlled laboratory conditions. These authors did not investigate the suitability of the diets compared to other diets, for all developmental stages of O. sacchari.

The paucity of information is related to the lack of a proven suitable diet for continuous rearing of this insect in the laboratory. Insect laboratory rearing fed on an artificial diet can help to understand the pest biology and ecology and provide a continuous supply of insects for study, which can aid in developing control programs (Parra 2000). 
Aiming to improve knowledge of the biological, ecological, and behavioral characteristics of $O$. sacchari, this study evaluated three artificial diets for rearing larvae of this species.

\section{Material and Methods}

\section{Biological assessment}

Larvae and pupae were collected in several banana plantations in the municipality of Luiz Alves, Santa Catarina, southern Brazil (S-26.713457, W-48.912200). After their emergence, adults were placed in cages made of polyvinyl chloride (PVC) pipe $(20 \mathrm{~cm}$ height $\times 10 \mathrm{~cm}$ diameter) lined with bond paper as an oviposition substrate. Translucent plastic Petri dishes were used to close the ends of the pipe. A piece of bond paper folded in a fan was placed in each cage, to serve as an additional oviposition substrate. The adult moths were fed with a solution of $10 \%$ honey in water (Bergmann et al 1995), placed in a glass tube $(4.5 \mathrm{~cm}$ height $\times 2 \mathrm{~cm}$ diameter $)$, and covered with dental cotton to supply the solution by capillarity. The newly hatched larvae were "inoculated" in one of the three diets tested: Diet 1, based on the diet developed by Greene et al (1976); Diet 2, based on the diet of Hensley and Hammond (1968); and Diet 3, based on that of Bowling (1967) (see the modification in Table 1). These three diets were chosen because they all support a wide range of insects (Singh 1977). Each larva was placed in an individual glass vial $(2.3 \times 8 \mathrm{~cm})$ containing approximately $20 \mathrm{~mL}$ of the diet and closed with hydrophobic cotton; 150 tubes were set up per diet. The tubes were kept sloping in wooden holders in an airconditioned room at a temperature of $25 \pm 2{ }^{\circ} \mathrm{C}, \mathrm{RH}$ $60 \pm 10 \%$, and photophase of $14 \mathrm{~h}$. The tubes with larvae were inspected daily, in order to determine the length of the larval and prepupal-pupal periods. The viability of larvae was measured by dividing the initial number of larvae by the number of individuals that reached the prepupal stage. Similarly, the prepupal-pupal viability was measured by dividing the number of individuals that formed a cocoon by the number of adults that emerged. The prepupal and pupal periods were measured together because the larvae produce a silk cocoon that obscures the beginning of the pupal stage.

The adults were sexed using morphological characters on the end of their abdomen (Bergmann et al 1995). After the adults emerged, 20 couples were formed and placed in individual $10-\mathrm{cm}$ white PVC cages, kept in an incubator programmed to maintain a constant $25 \pm 1^{\circ} \mathrm{C}, \mathrm{RH} 60 \pm 10 \%$, and photophase of $14 \mathrm{~h}$ to assess the adult longevity and fertility. The female weight was assessed from 20 individuals, from each diet, collected from the tubes and not used to form the couples.

At 3-day intervals, the bond paper lining the cage and the paper fan, now with eggs, were replaced, and the bond paper with eggs was stored in a freezer for subsequent counting. An exception was the eggs laid on the second day, which were immediately used to assess egg parameters. The viability and duration of eggs laid were assessed by dividing the eggs from the second laying day into batches of ten and placing them in Petri dishes ( $9.5 \mathrm{~cm}$ diameter) containing filter paper. Ten Petri dishes were prepared for each diet. The dishes were kept at a temperature of $25 \pm 1^{\circ} \mathrm{C}, \mathrm{RH}$ $60 \pm 10 \%$, and photophase of $14 \mathrm{~h}$. Eggs that remained unhatched 6 days after the first eggs laid on the same day started to hatch were considered non-viable. Eggs from which the larvae hatched were considered viable, and the period between egg laying and larval hatching was considered the egg period.

Dr. Vitor Osmar Becker, a specialist on Lepidoptera, confirmed the taxonomic identity of the specimens.

\section{Corrected biotic potential}

To compare the diets, the corrected biotic potential (CBP) was used as modified by Vendramim \& Parra (1986), based on the biotic potential proposed by Chapman (1928). The CBP can be used as an alternative to life-table analyses; a higher CBP indicates a higher insect fitness. The CBP was calculated using the following equation:

\section{$\mathrm{CBP}=\mathrm{Rp}-\mathrm{Er}$}

Where:

$\mathrm{CBP}=$ Corrected biotic potential;

$\mathrm{Rp}=$ Reproductive potential;

$\mathrm{Er}=$ Environmental resistance; which includes the abiotic factors and also the biotic factors of the environment (Chapman 1928).

Since the study was done in the laboratory, the environmental resistance $\mathrm{Er}$ was set equal to $\mathrm{O}$, because the laboratory conditions were considered optimal for this species; therefore, $C B P=R p$ :

with

$\mathrm{Rp}=(\mathrm{sr} \times \Omega)^{g}$

Where,

$s r=\operatorname{sex}$ ratio, $\left(\frac{\text { number of females }}{\text { number of females }+ \text { number of males }}\right)$

$\Omega=$ number of offspring; in this case, the number of eggs (fertility) multiplied by the viability of $O$. sacchari from egg to 
Table 1 Composition of the test diets: Diet 1, based on Greene et al (1976); Diet 2, based on Hensley and Hammond (1968); and Diet 3, based on Bowling (1967).

\begin{tabular}{|c|c|c|c|c|c|c|}
\hline & Diet 1 & & Diet 2 & & Diet 3 & \\
\hline Components & Quantity & $\begin{array}{l}\text { Proportion } \\
(\%)^{\mathrm{a}}\end{array}$ & Quantity & $\begin{array}{l}\text { Proportion } \\
\text { (\%) }\end{array}$ & Quantity & $\begin{array}{l}\text { Proportion } \\
\text { (\%) }\end{array}$ \\
\hline Beans (Carioca variety) & $250 \mathrm{~g}$ & 5.08 & - & - & 100 & 11.35 \\
\hline Wheat germ & $200 \mathrm{~g}$ & 4.07 & 108 & 2.93 & - & - \\
\hline Soy bran & $100 \mathrm{~g}$ & $2.03^{b}$ & - & - & - & - \\
\hline Granulated sugar & - & - & 180 & $4.88^{b}$ & - & - \\
\hline Brewer's yeast & $125 \mathrm{~g}$ & $2.44 b$ & - & - & 15 & 3.47 \\
\hline Casein & $74 \mathrm{~g}$ & 2.03 & 108 & 2.93 & - & - \\
\hline Vitamin solution ${ }^{\mathrm{bc}}$ & $20 \mathrm{~mL}$ & 0.61 & 36 & 0.98 & - & - \\
\hline Choline chloride & - & - & 3.6 & 0.10 & - & - \\
\hline Wesson's salt & - & - & 36 & 0.98 & - & - \\
\hline Ascorbic acid & $12 \mathrm{~g}$ & 0.24 & 14.4 & 0.39 & 1.5 & 0.35 \\
\hline Sorbic acid & $6 \mathrm{~g}$ & 0.12 & - & - & 0.5 & 0.11 \\
\hline $\begin{array}{l}\text { Methyl } \\
\text { parahydroxybenzoate } \\
\text { (nipagin) }\end{array}$ & $10 \mathrm{~g}$ & 0.20 & 5.4 & 0.15 & 1.0 & 0.22 \\
\hline Tetracycline & $0.25 \mathrm{mg}$ & 0.007 & 1 & 0.03 & - & - \\
\hline Formaldehyde $(37 \%)^{b}$ & $12 \mathrm{~mL}$ & 0.24 & 1.8 & 0.05 & 1.0 & 0.86 \\
\hline Carrageenan $^{\mathrm{b}}$ (agar) & $46 \mathrm{~g}$ & 1.56 & 72 & 1.95 & 9.0 & 1.41 \\
\hline Distilled water & $3400 \mathrm{~mL}$ & 81.35 & 3116 & 84.64 & 3750 & 82.22 \\
\hline
\end{tabular}

${ }^{\text {a }}$ All concentrations were modified from the original diet.

${ }^{\mathrm{b}}$ Ingredient modified from the original diet.

${ }^{\mathrm{c}}$ Vitamin solution: dry ingredients (niacinamide $1.00 \mathrm{~g}$; calcium pantothenate $1.00 \mathrm{~g}$; riboflavin $0.50 \mathrm{~g}$; thiamine $0.25 \mathrm{~g}$; pyridoxine $0.25 \mathrm{~g}$; folic acid $0.10 \mathrm{~g}$; biotin $0.02 \mathrm{mg})$; wet ingredient: vitamin $B_{12}(1000 \mathrm{mg} / \mathrm{mL}) 2.00 \mathrm{~mL}$. The dry and wet ingredients were mixed in $1 \mathrm{~L}$ distilled water. adulthood, i.e., the number of eggs that generated adults. This differs from the proposal by Chapman (1928), who did not include the viability of the different life stages; $g=$ number of generations during a period, in this case 1 year.

\section{Data analyses}

For the duration of the development times of eggs, larvae, and prepupae-pupae, as well as adult longevity, Kaplan-
Fig 1 Duration of egg $\pm \mathrm{SE}$, larval $\pm \mathrm{SE}$, and prepupal/pupal $\pm \mathrm{SE}$ periods of Opogona sacchari reared on three different diets. The eggs assessed came from insects reared on the three different diets. Temperature $25^{\circ} \mathrm{C}$; $\mathrm{RH} 60 \%$; photophase $14 \mathrm{~h}$. Means followed by the same letter do not differ in the log-rank test $(p<0.05)$. Statistics: egg $\chi^{2}=0 ; \mathrm{df}=2 ; p=0.98$; larvae $\chi^{2}=222 ; \mathrm{df}=2 ; p=0 ;$ prepupaepupae $\chi^{2}=19.5 ; \mathrm{df}=2 ; p<0.01$. Protein source: Diet 1 bean, wheat germ, soy bran, brewer's yeast, casein; Diet 2 wheat germ, casein; Diet 3 bean, brewer's yeast.

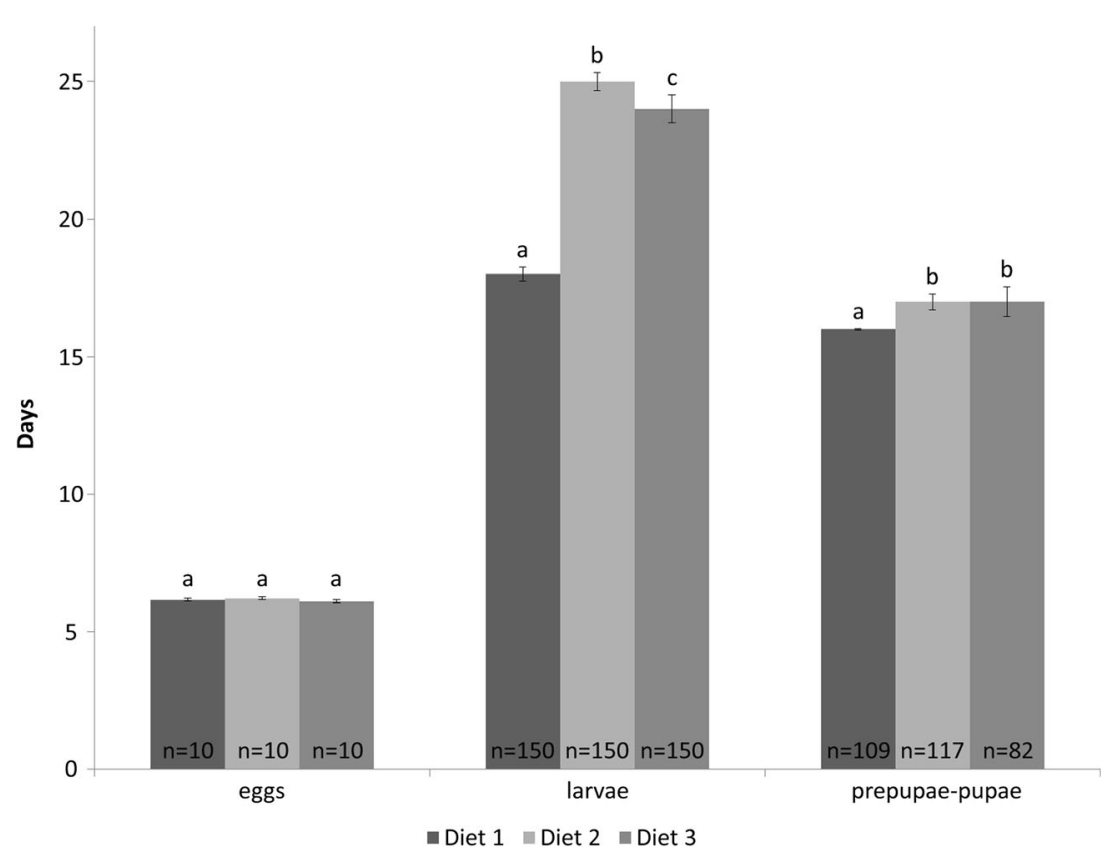


Fig 2 Viability of egg-adult \pm SE period of Opogona sacchari reared on three different diets. Temperature $25^{\circ} \mathrm{C}$; $\mathrm{RH} 60 \%$; photophase $14 \mathrm{~h}$. The eggs assessed came from insects reared on the three different diets. Means followed by the same letter do not differ statistically $(p<0.05)$. Statistics: egg, $F=0.20 ; \mathrm{df}=2 ; p=0.75$; larvae $\chi^{2}=10.6 ; \mathrm{df}=2 ; p<0.01$; prepupae-pupae $\chi^{2}=3.7 ; \mathrm{df}=2$; $p<0.01$. Diet 1 bean, wheat germ, soybean bran, brewer's yeast, casein; Diet 2 wheat germ, casein; Diet 3 bean, brewer's yeast.

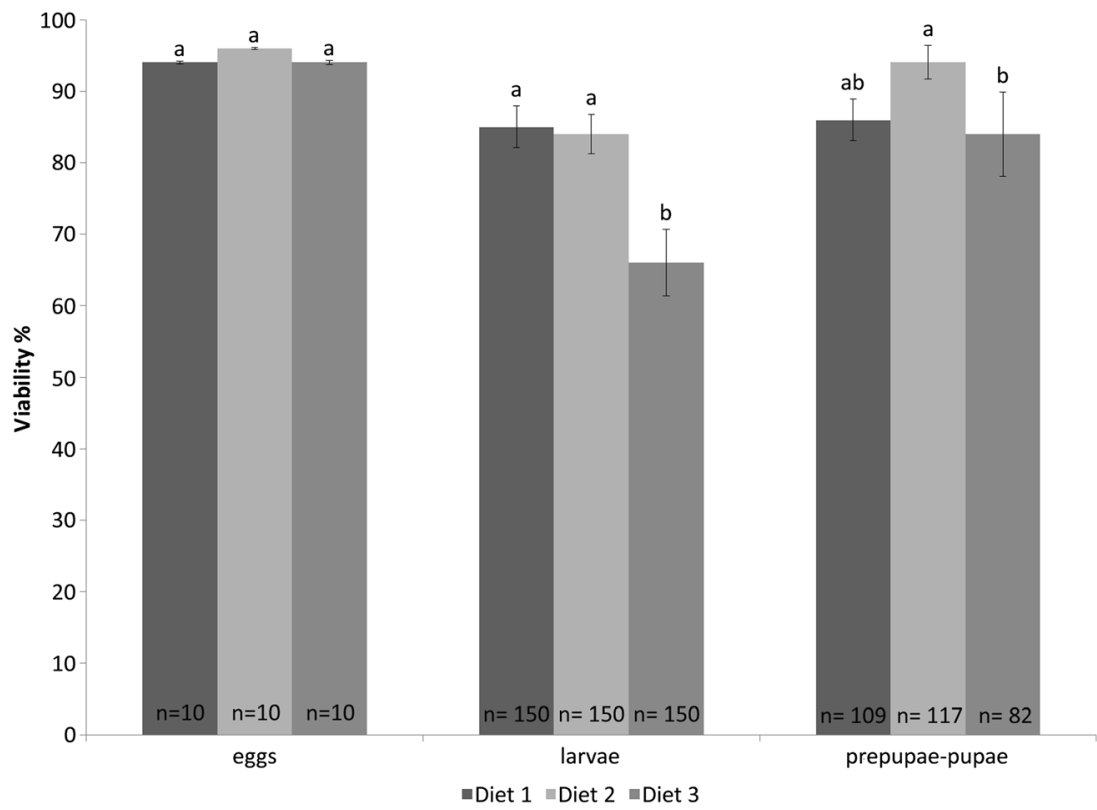

Meier estimators were obtained for each treatment (Therneau 2015). To test for significant differences, pairwise tests were performed using log-rank tests (Matthews \& Farewell 2007). For the data on egg viability and sex ratio, quasi-binomial generalized linear models were fitted; and for the fecundity data, a quasi-Poisson generalized linear model was fitted. The effects were tested with an $F$ test, because the data were overdispersed (Demétrio et al 2014). Binomial generalized linear models were fitted to the data for the viability during the larval and prepupal-pupal periods, and an analysis of deviance was carried out to assess the significance of the effects. An analysis of variance model was fitted to the data for female weight. When there were significant treatment effects $(p<0.05)$, multiple comparisons were performed by obtaining the $95 \%$ confidence intervals for the linear predictors for the generalized linear models; and for the analysis of variance model, a Tukey test was performed. Goodness-of-fit for all models was assessed using halfnormal plots with a simulated envelope package (Moral et al 2016). A cluster analysis was carried out and a dendrogram was obtained to rank the diets according to total viability, fertility, sex ratio, and egg-adult period, using Euclidean distance. The corrected biotic potential was compared using $95 \%$ bootstrap confidence intervals from 10,000 simulations of the values for each treatment. Since values between $1.71^{14}$ and $1.19^{18}$ were found, they were transformed
Table 2 Total egg-adult period, viability, fecundity, and life span of Opogona sacchari fed on three different diets.

\begin{tabular}{|c|c|c|c|c|c|}
\hline \multirow[t]{2}{*}{ Diet } & \multirow{2}{*}{$\begin{array}{l}\text { Egg-adult } \\
\text { period (days)* }\end{array}$} & \multirow{2}{*}{$\begin{array}{l}\text { Viability in egg-adult } \\
\text { period }(\%)^{* *}\end{array}$} & \multirow[t]{2}{*}{ Fertility*** } & \multicolumn{2}{|c|}{ Adult longevity (days)** } \\
\hline & & & & $\sigma^{\lambda}$ & 우 \\
\hline $\operatorname{Diet} 1^{\mathrm{a}}$ & $40 \pm 0.35 a$ & $68.5 \pm 2.76 a b$ & $338.42 \pm 39.83$ & $21.0 \pm 1.5 \mathrm{abA}$ & $14.0 \pm 0.6 \mathrm{~B}$ \\
\hline Diet $2^{b}$ & $48 \pm 0.61 b$ & $75.8 \pm 3.27 a$ & $364.00 \pm 51.35$ & $19.0 \pm 0.6 \mathrm{bA}$ & $14.0 \pm 0.4 B$ \\
\hline Diet $3^{c}$ & $47 \pm 0.88 b$ & $51.6 \pm 7.30 \mathrm{~b}$ & $293.70 \pm 50.64$ & $23.5 \pm 1.2 \mathrm{aA}$ & $16.0 \pm 0.6 \mathrm{~B}$ \\
\hline Statistics & $\begin{array}{c}\chi^{2}=37 ; d f=2 ; \\
p<0.01\end{array}$ & $\begin{array}{c}\mathrm{F}=5.38 ; \mathrm{df}=2 ; \\
\quad p=0.01\end{array}$ & $\begin{array}{c}\mathrm{F}=0.55 ; \mathrm{df}=2 ; \\
p=0.57\end{array}$ & $\begin{array}{c}\chi^{2}=94.6 \\
\mathrm{df}=2 \\
p=0\end{array}$ & \\
\hline
\end{tabular}

Temperature: $25 \pm 1^{\circ} \mathrm{C}, \mathrm{RH}: 60 \pm 10 \%$, photophase: $14 \mathrm{~h}$.

*Means followed by the same letter do not differ in the Log-rank test $(p<0.05)$; **means followed by the same letter do not differ statistically in the Tukey test $(p<0.05)$; **no statistical difference by quasi-Poisson GLM model.

${ }^{\text {a }}$ Protein source: bean, wheat germ, soy bran, brewer's yeast, casein.

${ }^{\mathrm{b}}$ Protein source: wheat germ, casein.

'Bean, brewer's yeast. 
Table 3 Corrected biotic potential (CBP) of Opogona sacchari on three different diets, for 365 days.

\begin{tabular}{lllll}
\hline Diet & Absolute value & Bootstrap Cl* & Logarithm value & Logarithm bootstrap Cl* \\
\hline Diet $1^{\mathrm{a}}$ & $1.19^{18}$ & $9.9^{16}: 1.16^{19} \mathrm{a}$ & 18.08 & $17.00: 19.07 \mathrm{~b}$ \\
${\text { Diet } 2^{\mathrm{b}}}^{1.77^{16}}$ & $1.95^{15}: 1.11^{17} \mathrm{ab}$ & 16.25 & $15.29: 17.05 \mathrm{ab}$ \\
Diet $^{\mathrm{c}}$ & $1.71^{14}$ & $7.2^{12}: 2.48^{15} \mathrm{~b}$ & 14.25 & $12.86: 15.4 \mathrm{~b}$ \\
\hline
\end{tabular}

CBP (absolute value) and logarithm value and the respective confidence intervals calculated by bootstrap.

* Confidence interval followed by the same letter do not differ (significancy $95 \%$ from 10,000 simulations).

a Protein source: dried beans, wheat germ, soy bran, brewer's yeast, casein.

${ }^{b}$ Protein source: wheat germ, casein.

${ }^{\mathrm{c}}$ Protein source: dried beans, brewer's yeast. to logarithm scale to better express the CBP. All analyses were carried out in R software ( $\mathrm{R}$ Development Core Team 2015).

\section{Results and Discussion}

None of the diets affected the duration and viability of O. sacchari eggs (Figs 1 and 2). Eggs laid by the females reared on the three different diets showed a similar embryonic period of around 6 days, with viability greater than $94 \%$.

The diets affected the duration and viability of the larval and prepupal-pupal stages and consequently the total duration and survival (Figs 1 and 2, Table 2). For Diet 1, the larval period was $18 \pm 0.24$ days, at least 6 days shorter than the periods obtained with the other experimental diets. The percentages of larval survival were statistically similar ( $84 \pm 3.13 \%$ and $85 \pm 3.22 \%$, respectively) for Diets 1 and 2 , higher than the $66 \pm 7.77 \%$ obtained with Diet 3 (Figs 1 and 2). Gianotti et al (1977) reported that the larval period of $O$. sacchari ranges from 42 to 70 days with a diet based on bananas, although they did not report the temperature at which the insects were reared. The larval period with a diet based on cornflakes was 58 days (Mourikis \& VassilainaAlexopoulou apud Bergmann et al 1995). The data of Bergmann et al (1995) were similar to those obtained in the present study, i.e., the larval period lasted 24.19 days with a bean-based diet and a temperature of $25 \pm 1^{\circ} \mathrm{C}, \mathrm{RH} 70 \%$, and photophase $12 \mathrm{~h}$.

The prepupal-pupal period lasted at least 16 days, and again, Diet 1 provided the faster development. Diet 2 supported high viability for this phase of development, with an emergence rate higher than $94 \%$ (Figs 1 and 2). The period obtained by Bergmann et al (1995) was 11.24 days under similar environmental conditions. This 5-day difference in the duration of the pupal stage may be related to the initiation of observations at the prepupal stage, because of the obscuring silk cocoon (see Material and Methods).

The sex ratio did not vary $\left(\chi^{2}=10.6, \mathrm{df}=2\right.$, $p=0.76)$ and was consistently 0.5 . The weight of females was similar for all diets $(F=2.8, \mathrm{df}=2$, $p=0.07)$, ranging from 32 to $35 \mathrm{mg}$. Females had lower longevity than males under the rearing conditions. Fertility was also not affected by the different diets, averaging over 290 eggs per female $\left(\chi^{2}=10.6\right.$, $\mathrm{df}=2, p=0.76)$ (Table 2). Daumal \& Boinel (1994), Chapman (1998) and Coelho \& Parra (2013) mentioned that there is a direct relationship between female weight and egg production, which can explain the similar fertility obtained in this study.

Over a long rearing period ( 1 year), Diets 1 and 2 gave the best values of CBP (Table 3). Although Diet 2 provided an overall $75.8 \%$ viability, an acceptable value for insect laboratory rearing according to Singh (1983), the CBP value for a longer period was similar to that obtained with Diet 1 . This relatively high CBP for insects reared with Diet 1 , based on dried beans, wheat germ, soy bran, brewer's yeast, and casein, is explained by the shorter egg-adult period, which provides at least two more generations of $O$. sacchari per year under laboratory conditions. The dendrogram composed from all biological parameters measured shows the similarity between Diets 1 and 2, which concords with the results for the corrected biotic potential. The biological parameters of
Fig 3 Dendrogram of the biological characteristics (total viability, fertility, sex ratio, and egg-adult period) of Opogona sacchari reared on the different diets.

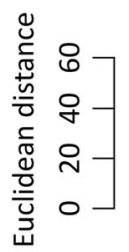

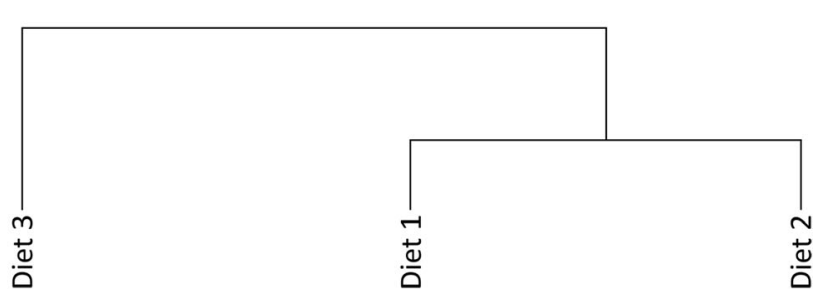


O. sacchari reared on Diets 1 and 2 were grouped into the same clade at a distance of $30 \%$, separating them from Diet 3 (Fig 3).

Therefore, based on the biological results, diets based on dried beans, wheat germ, soy bran, brewer's yeast, and casein (Diet 1) and wheat germ and casein (Diet 2) can be used for rearing $O$. sacchari. These are the first artificial diets studied specifically for this target species, under controlled laboratory conditions.

Acknowledgments We thank Janet W. Reid, JWR Associates, for the English revision and the anonymous reviewer for all criticisms and suggestions. We also thank the National Institute of Semiochemicals in Agriculture (INCT; process no. 573761/2008-6) and the National Council for Scientific and Technological Development (CNPq; process no. $164513 / 2015-9)$ for the financial support.

\section{References}

Bergmann EC, Romanholi RC, Potenza MR, Imenes SL, Zorzenon FJ, Rodrigues Netto SMR (1995) Aspectos biológicos e comportamentais de Opogona sacchari (Bojer, 1856) (Lepidoptera: Tineidae), em condições de laboratório. Rev Agric 70:41-52

Bowling CC (1967) Rearing of two lepidopterous pests of rice on a common artificial diet. Ann Entomol Soc Am 60:1215-1216

Chapman RN (1928) Quantitative results in the prediction of insect abundance on the basis of biotic potential and environmental resistance. J Econ Entomol 21:349-352

Chapman RF (1998) The insects: structure and function, 4th ed. Cambridge University Press, Cambridge

Cintra AF (1975) Opogona sp. nova praga da bananicultura. O Biológico 41:223-231

Coelho A Jr, Parra JRP (2013) The effect of rearing in different temperature regimes on the reproduction of Anagasta kuehniella (Lepidoptera: Pyralidae). Environ Entomol 42:799-804

Daumal J, Boinel H (1994) Variability in fecundity and plasticity of oviposition behavior in Anagasta kuehniella (Lepidoptera: Pyralidae). Ann Entomol Soc Am 87:250-256

Demétrio CGB, Hinde J, Moral RA (2014) Models for overdispersed data in entomology. In: Ferreira CP, Godoy WAC (eds) Ecological modeling applied to entomology. Springer, Cham, pp 219-259

(EPAGRI) Empresa de Pesquisa Agropecuária e Extensão Rural de Santa Catarina (2016) Banana: recomendações técnicas para o cultivo em Santa Catarina. <http://www.epagri.sc.gov.br/?page-id=1349>

(EPPO) European and Mediterranean Plant Protection Organization (2015) EPPO A1 and A2 lists of pests recommended for regulation as quarantine pest. http://archives.eppo.int/EPPOStandards/PM1_ GENERAL/pm1-02(24)_A1A2_2015.pdf

Gallo D, Nakano O, Silveira-Neto S, Carvalho RPL, Baptista GC, Berti Filho E, Parra JRP, Zucchi RA, Alves SB, Vendramim JD, Marchini LC, Lopes JRS, Omoto C (2002) Entomologia agrícola. Fealq, Piracicaba

Gianotti O, Oliveira BS Jr, Toneda T, Fell D (1977) Observações gerais sobre o desenvolvimento e comportamento sexual do lepidóptero Opogona sacchari (Bojer, 1856) em laboratório. Arq Inst Biol 44: 209-212

Greene GL, Leppla NC, Dickerson WA (1976) Velvetbean caterpillar: a rearing procedure and artificial medium. J Econ Entomol 69:487-488

Hensley SD, Hammond AM (1968) Laboratory techniques for rearing the sugarcane borer on an artificial diet. J Econ Entomol 61:1742-1743

Heppner JB, Pena JE, Glenn H (1987) The banana moth, Opogona sacchari (Bojer) (Lepidoptera: Tineidae), in Florida. Entomology Circular No. 293, Fla. Dept. Agric. and Consumer Serv. Division of Plant Industry

Matthews DE, Farewell VT (2007) The log-rank or Mantel-Haenszel test for the comparison of survival curves. In: Matthews DE, Farewell VT (eds) Using and understanding medical statistics. Karger, Basel, pp 67-75

Milanez JM, Hinz RH, da Silva CM (2011) Aspectos biológicos da traça-dabananeira. Agropecu Catarin 24:92-94

Moral RA, Hinde J, Demétrio CGB (2016) hnp: half-normal plots with simulation envelopes. $\mathrm{R}$ package version 1.2-1.

Parra JRP (2000) A biologia de insetos e o Manejo de Pragas: Da criação em laboratório à aplicação em campo. In: Guedes JC, Costa ID, Castiglioni E (eds) Bases e Técnicas do Manejo de Insetos. UFSM, Santa Maria, pp 1-29

R Development Core Team (2015) R: a language and environmental for statistical computing. Version 3.1.1. R Foundation for Statistical Computing. Vienna, Austria

Raga A (2005) Principais pragas da bananeira e método de controle, pp. 9-13 In: Proceedings, 13 a Reunião Itinerante de Fitossanidade do Instituto Biológico, 23-24 November, 2005, Registro, SP. IB, São Paulo, Brazil

(SENASA) Servicio Nacional de Sanidad y Calidad Agroalimentaria (2016) <https://www.ippc.int/static/media/files/reportingobligation/2016/ 02/16/Quarantine_Pest_List_of_Argentina_-_2016.pdf>

Singh P (1977) Artificial diets for insects, mites, and spiders. Plenum, New York, 594p

Singh P (1983) A general purpose laboratory diet mixture for rearing insects. Insect Sci Appl 4:357-362

Therneau T (2015) A package for survival analysis in S. version 2.38

(USDA) U.S. Department of Agriculture/ APHIS Animal and Plant Health Inspection Service (2016) Regulated pest list <https://www.aphis. usda.gov/import_export/plants/plant_imports/downloads/ RegulatedPestList.pdf

Vendramim JD, Parra JRP (1986) Utilização do índice Potencial Reprodutivo Corrigido em estudos de resistência de plantas a insetos, p. 173 In: Proceedings, X Congresso Brasileiro de Entomologia, Rio de Janeiro, RJ 